\title{
PERANCANGAN SISTEM INFORMASI KEUANGAN BOUTIQUE
}

\author{
Alhamidi \\ Teknologi Informasi, Institut Teknologi Batam, \\ Jl. Gajah Mada, Kompleks Vitka City Tiban Ayu - Sekupang Batam \\ Email : mi_owen@yahoo.com
}

\begin{abstract}
The rapid development of technology makes it possible to get accurate and fast information. Boutiqe engaged in the clothing business is difficult to get accurate information on sales results due to data - sales results are still calculated manually, so Boutiqe financial information can not explain how much profit should be obtained. Weaknesses in getting accurate financial information then a computer-based information system was built that could store all sales data and produce more accurate financial reports. The information system built uses MYSQL as a data storage database.
\end{abstract}

Keywords: Boutiqe, Finance, MYSQL, Information Systems

\begin{abstract}
Abstrak
Perkembangan teknologi yang semakin pesat memungkinkan untuk mendapatkajn informasi yang akurat dan cepat. Boutiqe yang bergerak dibidang usaha pakaian sulit mendapatkan informasi hasil penjualan yang akurat disebabkan oleh data - data hasil penjualan masih dihitung secara manual, sehingga informasi keuangan Boutiqe tidak bisa menjelaskan berapa keuntungan yang musti didapat. Kelemahan dalam mendapatkan informasi keuangan yang akurat maka dibangun sistem informasi berbasis komputer yang bisa menyimpan semua data - data penjualan dan menghasilkan laporan keuangan yang lebih akurat. Sistem informasi yang dibangun menggunakan MYSQL untuk sebagai database penyimpan data.
\end{abstract}

Kata Kunci : Boutiqe, Keuangan, MYSQL, Sistem Informasi

\section{PENDAHULUAN}

Pada saat ini kebutuhan informasi merupakan kebutuhan yang semakin meningkat dengan di tandai adanya perkembangan teknologi informasi yang digunakan untuk membuat data-data, menyimpan data dan pengolahan data.Tetapi teknologi tersebut harus ada peran pendukung seperti sistem informasi yang baik.
Dengan adanya komputer banyak pekerjaan yang bisa diselesaikan dalam pengolahan data-data dalam berbagai bidang untuk dijadikan informasi, seperti dalam bidang Accounting. Accounting sangat berperan dalam bidang penjualan untuk mengolah data-data dan menghitung pendapatan suatu usaha yang membutuhkan suatu tempat penyimpanan yang bersifat 
lebih akurat, agar data-data yang disimpan tidak sulit untuk dicari saat diperlukan.

Usaha Situs Boutiqe merupakan salah satu usaha yang bergerak di bidang penjualan pakaian wanita yang berada di Kota Padang. Dimana frekuensi pendapatannya selalu berubah-ubah. Namun pada usaha ini sistem yang digunakan masih dilakukan secara manual dan kegiatan pencatatannya pun masih belum memenuhi standar akuntansi, hal ini sering mengakibatkan terjadinya keterlambatan dan kesalahan dalam proses perhitungan dalam pembuatan rekap laporan penjualan hariannya. Seperti contoh, kasir menerima uang hasil penjualan dari konsumen setiap harinya, lalu membuat sebuah rekap penjualan dan kemudian diserahkan ke bagian Accounting. Bagian Accounting menyalin pendapatan dan pengeluaran harian kedalam buku laporan keuangan, begitulah siklus yang terjadi setiap harinya. Ketika pemilik meminta laporan keuangan, bagian Accounting memperlihatkan buku laporan yang ada. Tapi ketika pemilik meminta laporan bulanan ataupun tahunan, bagian Accounting terpaksa harus menghitung kembali dari catatan penghasilan harian yang ada. Dan itu membutuhkan waktu yang lama dan lagi pula kelemahan dari sistem manual ini adalah laporan keuangan yang tidak terjamin akurasinya karena manusia bisa saja khilaf.

Melihat kelemahan yang ada pada usaha Situs Boutique, penulis bermaksud membantu mempermudah agar pencatatan pendapatannya lebih efektif dan efisien. Oleh karena itu penulis bermaksud merancang sistem informasi untuk merekap semua transaksi pembuatan laporan pendapatan dan pengeluaran tersebut harus menggunakan sistem yang terkomputerisasi dengan baik.

\section{Pengertian Sistem}

Terdapat dua kelompok pendekatan di dalam mendefenisikan sistem, yaitu yang menekankan pada prosedurnya dan yang menekankan pada komponen atau elemennya. Pendekatan sistem yang lebih menekankan pada prosedurnya mendefenisikan sistem sebagai berikut:

Sistem adalah kumpulan dari elemenelemen yang berinteraksi untuk mencapai suatu tujuan tertentu (Jogiyanto, 2005).

Menurut L.James Havery (2009) sistem merupakan Prosedur logis dan rasional untuk merancang suatu rangkaian komponen yang berhubungan satu dengan yang lainnya dengan maksud untuk berfungsi sebagai suatu kesatuan dalam usaha mencapai suatu tujuan yang telah ditentukan

Sedangkan dalam buku karya Yakub (2012), sistem adalah sekelompok elemenelemen yang terintegrasi dengan tujuan yang sama untuk mencapai tujuan (MCLeod 2014).

\section{Karakteristik Sistem}

Suatu sistem mempunyai karakteristik atau sifat-sifat yang tertentu, yaitu Mempunyai komponen-komponen (component), batas sistem (boundary), lingkungan luar sistem (environments), penghubung (interface), masukan (input), keluaran (output), pengelola (process), dan sasaran (objectives), Sasaran (goal) (Jogiyanto, 2005). :

\section{Komponen Sistem}

Suatu sistem terdiri dari sejumlah komponen yang saling berinteraksi, yang artinya saling bekerja sama membentuk satu kesatuan.

\section{Batasan Sistem}


Batas sistem (boundary) merupakan daerah yang membatasi antara suatu sistem dengan sistem yang lainnya atau dengan lingkungan luarnya.

\section{Lingkungan Luar Sistem}

Lingkungan luar (environment) dari suatu sistem adalah apapun di luar batas dari sistem yang mempengaruhi operasi sistem.

\section{Penghubung Sistem}

Penghubung (interface) merupakan media penghubung antara satu sub sistem dengan sub sistem yang lainnya.

\section{Masukan Sistem}

Masukan (input) adalah energi yang dimasukan kedalam sistem.

\section{Keluaran Sistem}

Keluaran (output) adalah hasil dari energy yang diolah dan diklasifikasikan menjadi keluaran yang berguna dan sisa pembuangan.

\section{Pengolahan Sistem}

Suatu sistem dapat mempunyai suatu bagian pengolah yang akan merubah masukan menjadi keluaran.

8. Sasaran Sistem

Suatu sistem pasti mempunyai tujuan (goal) atau sasaran (objectives).

\section{Pengertian Informasi}

Informasi adalah data-data yang dikumpulkan dan diolah atau diproses dengan menggunakan program dan menghasilkan laporan yang dapat membantu seseorang ataupun pihak-pihak manajemen dalam mengambil suatu keputusan.

Informasi adalah data yang diolah menjadi bentuk yang lebih berguna dan lebih berarti bagi yang menerimanya(Jogiyanto, 2005).

Menurut McLeod, 2014 informasi adalah data yang telah menjadi bentuk lebih berguna dan lebih berarti bagi yang menerimanya. Informasi juga disebut data yang diproses atau data yang telah diproses sedemikian rupa sehingga meningkatkan pengetahuan seseorang yangmenggunakan. Data yang diolah atau diproses menjadi sebuah informasi dan bentuk yanglebih berguna serta berarti bagi siapa saja yang akan menerimanya. Suatu informasi tidak hanya merupakan serangkaian gagasan konsep semata. Namun informasi menentukan apa yang harus dikerjakan oleh sistem personil atau yang ada di dalam sistem tersebut dan informasi ini disainnya ditentukan oleh kebutuhan yang tidak saja harus dikerjakan, melainkan juga harus bernilai.

\section{Siklus Hidup Pengembangan Sistem (System Development Life Cycle/ SDLC)}

Didalam merancang suatu sistem, sistem analis cenderung berpedoman kepada siklus hidup pengembangan sistem. Proses pengembangan sistem melewati beberapa tahapan, mulai dari sistem tersebut direncanakan sampai sistem tersebut diterapkan, dioperasikan dan dipelihara. Tahapan-tahapan ini sangat penting bagi sistem karena dapat menjadikan sistem bertahan lama.

Adapun bentuk bagan dari Siklus Hidup Pengembangan Sistem (SDLC) beserta tahapan-tahapan yang dilalui dapat dilihat pada gambar 1 . 


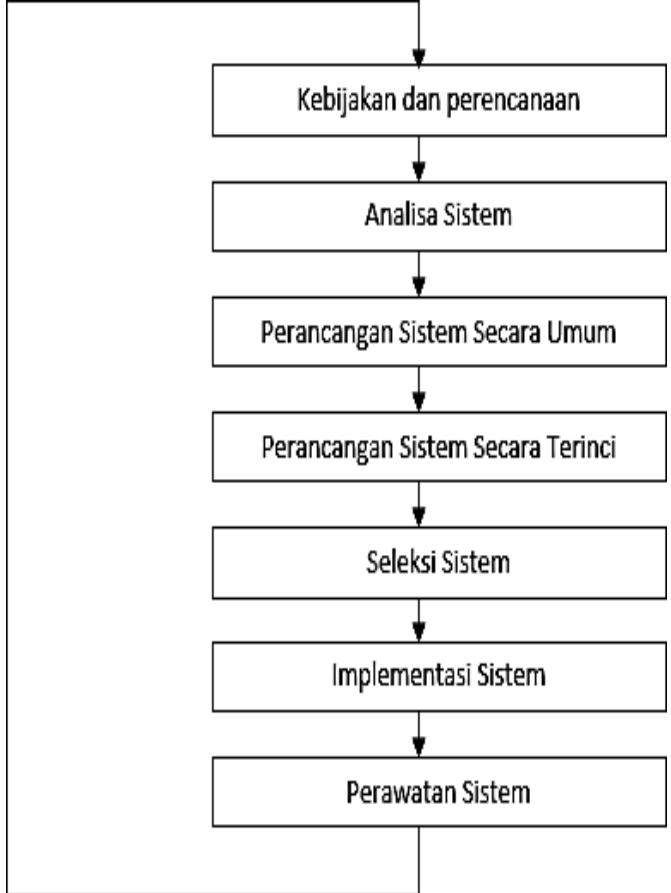

Gambar 1. Siklus Pengembangan Sistem

Tahap - tahap dari SDLC adalah sebagai berikut :

1. Tahap Kebijakan dan Perencanaan Sistem

Sebelum suatu sistem informasi dikembangkan, umumnya terlebih dahulu dimulai dengan adanya suatu kebijakan dan perencanaan untuk mengembangkan sistem itu. Tanpa adanya perencanaan sistem yang baik pengembangan sistem tidak akan berjalan sesuai dengan yang diharapkan. Kebijakan sistem merupakan landasan dan dukungan dari manajemen puncak untuk membuat perencanaan sistem. Perencanaan sistem merupakan pedoman unutk pengembangan sistem.

2. Tahap Analisa Sistem

Tahap ini dilakukan setelah tahap perencanaan sistem dan sebelum tahapdesain sistem. Tahap ini merupakan tahap yang kritis dan sangat pentingkarena kesalahan dan tahap ini akan menyebabkan kesalahan di tahapselanjutnya. Di dalam tahap ini terdapat langkah-langkah dasar yang harusdilakukan oleh analisis sistem sebagai berikut:

a. Identify yaitu mengidentifikasi masalah

b. Understand yaitu memahami kerja dari sistem yang ada

c. Analize yaitu menganalisa sistem

d. Report yaitu membuat laporan hasil analisis

3. Disain Sistem Secara Umum

Tujuan dari disain sistem secara umum adalah untuk memberikan gambaran secara umum kepada pengguna (user) tentang sistem yang baru. Disain sistem secara umum merupakan persiapan dari disain terinci. Disain secara umum mengidentifikasi komponen-komponen sistem informasi yang akan didisain secara terinci.

4. Disain Sistem Terinci

Pada tahap disain output secara umum, disain sistem terinci hanya dimaksudkan untuk menentukan kebutuhan output dari sistem baru. Disain output secara umum dimaksudkan untuk menjawab pertanyaan ini, bagaimana dan seperti apa bentuk dari output-output tersebut.

5. Tahap Seleksi

Hasil sistem ini belum dapat diimplementasikan, untuk itu komponen-komponen secara fisik perlu dimilki. Komponen fisik sistem ini adalah komponen teknologi yang dapat berupa perangkat keras dan perangkat lunak. Karena banyaknya alternatif teknologi yang tersedia dan banyaknya penyediaan teknologi dilakukan pada tahap ini. Tugas ini membutuhkan 
pengetahuan yang cukup bagi yang melaksanakannya agar dapat memenuhi kebutuhan rancang bangun yang telah dilakukan. Pengetahuan yang dibutuhkan oleh pemilih sistem diantaranya adalah pengetahuantentang siapa yang menyediakan teknologi ini dan sebagainya. Pemilih sistem juga harus paham dengan teknik evaluasi untuk menyelesaikan sistem.

6. Tahap Implementasi

Tahap ini merupakan tahap dimana suatu sistem siap untuk dioperasikan. Tahap ini terdiri dari langkah-langkah sebagai berikut:

a. Menerapkan rencana implementasi

b. Melakukan kegiatan implementasi

c. Tindak lanjut implementasi

7. Tahap Perawatan Sistem

Tahap ini merupakan tahap yang paling penting dan tahap akhir dalam sebuah pengembangan sistem, dimana tahapini lebih ditekankan kepada pemeliharaan sistem yang mengarah kepada manajemen sistem. Untuk itu pada tahap ini seorang analis sistem juga harus memikirkan apa tindakan terbaik yang perlu dilakukan dalam pengembangan sebuah sistem.

\section{METODE PENELITIAN}

Metodologi yang digunakan dalam melakukan penelitian ini adalah :

1. Penelitian Lapangan (Field Research) yaitu melakukan penelitian dengan menerapkan teknik wawancara secara langsung dengan pemilik situs boutiqe, dimana data yang diperoleh mencakup antara lain:

a.Aliran sistem informasi yang sedang berjalan padaSitus Boutiqe Padang. b. Format laporan yang dihasilkan pada Situs Boutiqe tersebut yang akan dimanfaatkan untuk Analisa sistem yang baru.

2. Penelitian Perpustakaan (Library Research)

Penelitian yang dilakukan untuk mendapatkan bahan-bahan yang secara teoritis dari berbagai buku yang berkaitan dengan permasalahan di atas.Teknik ini dilakukan untuk melengkapi dan menyempurnakan bahan-bahan dalam penyusunan skripsi ini.

3. Penelitian Laboraturium (Laboratory Research)

Pada penelitian laboratorium ini penulis langsung mengadakan penelitian terhadap informasi dan data-data yang diperoleh dari lapangan dan penelitian perpustakaan dengan menggunakan perangkat lunak (software) dan perangkat keras (hardware) yang dibutuhkan.

\section{HASIL DAN PEMBAHASAN}

\section{Aliran Sistem Informasi}

Merupakan bagan alir yang menunjukkan arus dari laporan dan formulir termasuk tembusan-tembusannya. Untuk itu dibutuhkan pedoman-pedoman untuk membuat Aliran Sistem Informasi (ASI). (Rini Asmara, 2014).

Aliran sistem informasi yang diusulkan adalah sebagai berikut :

a. Bagian Kasir dan bagian gudang memberikan laporan transaksi harian dan laporan pembelian barang dagang kepada bagian accounting.

b. Berdasarkan laporan transaksi harian dan laporan pembelian barang dagang yang diberikan oleh kasir dan bagian gudang, bagian accounting 
menginputkan data akun ke dalam database.

c. Berdasarkan database tersebut bagian accounting menginputkan jurnal trasaksi, dari jurnal transaksi tersebut bagian accounting mencetak laporan sebanyak 5 laporan masing - masing 2 rangkap.

d. Laporan yang di cetak tersebut yaitu laporan buku besar, laba/rugi, neraca saldo, jurnal transaksi, arus kas, dan perubahan modal.

e. Masing - masing satu rangkap laporan di berikan kepada pimpinan.

Pada gambar 2 berikut dapat dilihat aliran sitem informasi baru yang diusulkan, yang diharapkan bisa mengatasi kelemahan - kelemahan yang ada pada aliran sistem informasi yang lama. 


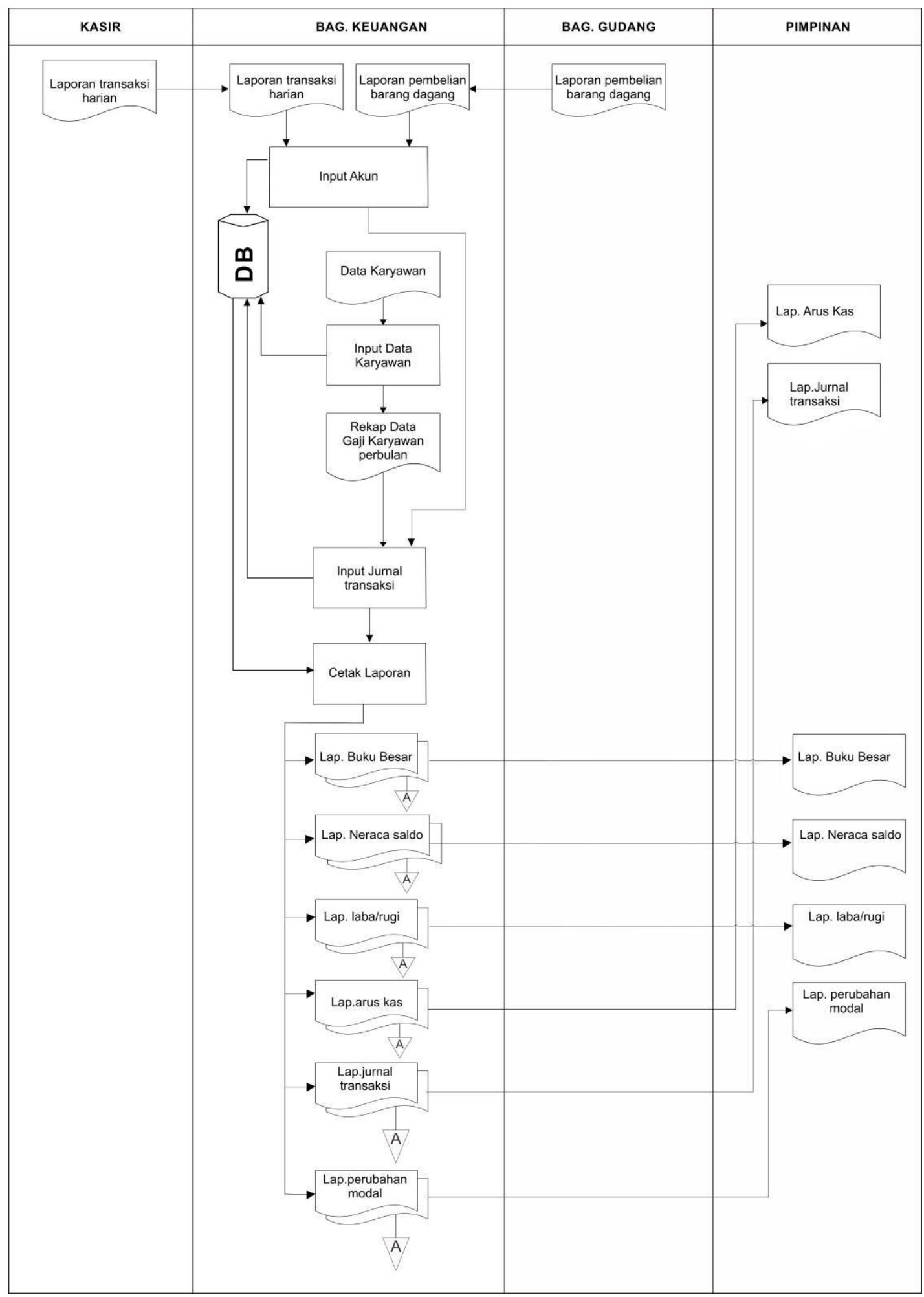

Gambar 2. Aliran Sistem Informasi Yang Diusulkan

\section{Contex Diagram}

Context Diagram merupakan data flow diagram yang menggambarkan garis besar operasional sistem. Konteks Diagram menggambarkan hubungan sistem dengan entitas-entitas diluar sistem. CD memperlihatkan sistem sebuah proses. Tujuannya adalah memberikan pandangan umum sistem. CD memperlihatkan sebuah proses yang berinteraksi dengan lingkungan 
luarnya. Ada pihak luar yang memberikan masukan dan pihak yang menerima keluaran sistem. (Rini Asmara, 2014)
Adapun gambar context diagram perusahaan boutiqe dapat dilihat pada gambar 3. berikut ini:

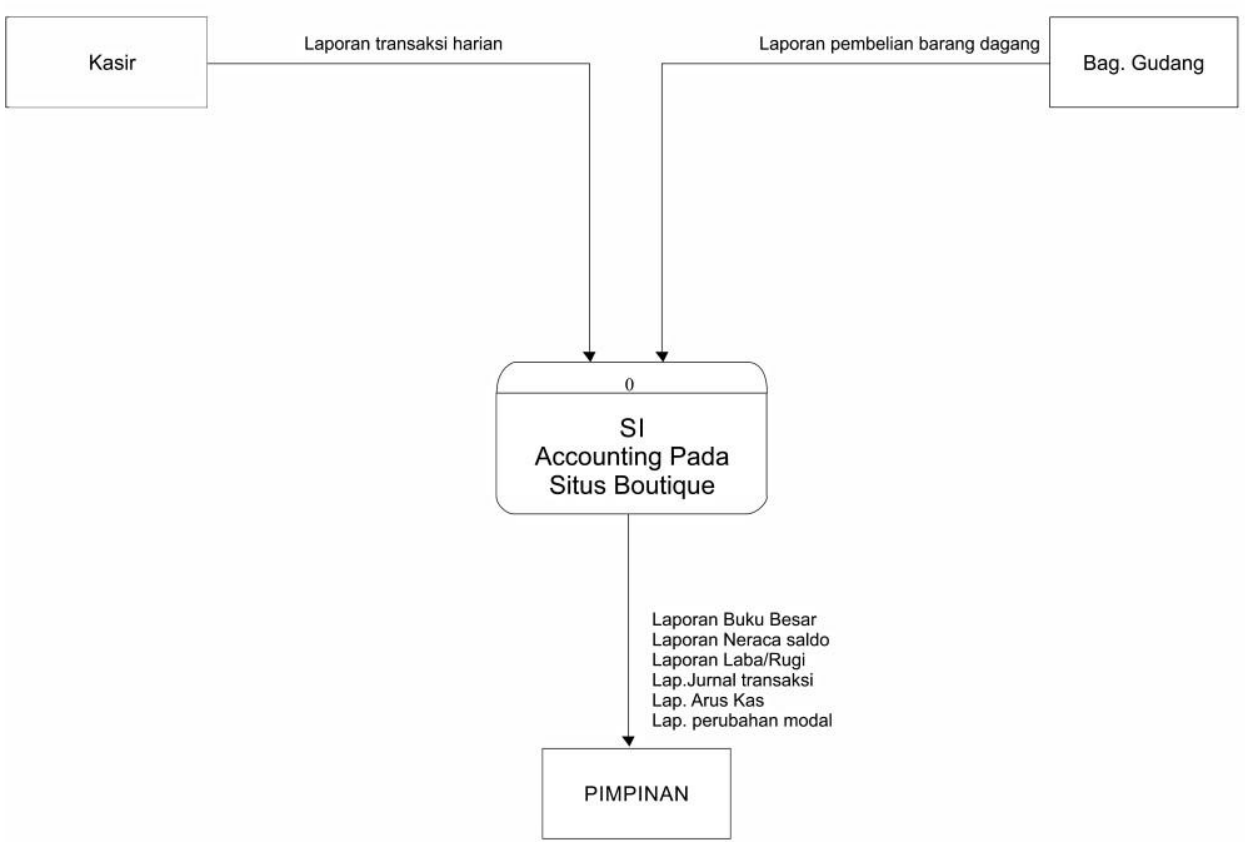

Gambar 3. Context Diagram

\section{Data Flow Diagram}

Diagram alir data sistem disebut juga dengan Data Flow Diagram (DFD). DFD sering digunakan untuk menggambarkan suatu sistem yang telah ada atau sistem baru yang akan dikembangkan secara logika tanpa mempertimbangkan lingkungan fisik dimana data tersebut mengalir atau lingkungan fisik disimpan. DFD menggambarkan arus data didalam sistem dengan terstruktur dan jelas. (Rini Asmara, 2014)
Data Flow Diagram (DFD) merupakan alat yang digunakan pada metodologi pengembangan sistem yang terstruktur. Data Flow Diagram (DFD) dapat menggambarkan aliran data dalam sistem yang terstruktur dan jelas, disamping itu Data Flow Diagram (DFD) juga merupakan dokumentasi dari sistem yang baik. Adapun DFD perusahaan boutiqe dapat dilihat pada gambar 4 sampai 5 dibawah ini :

a. Data flow diagram (DFD) Level 1 
Jurnal Teknologi Dan Sistem Informasi Bisnis

Vol. 2 No. 1 Januari 2020

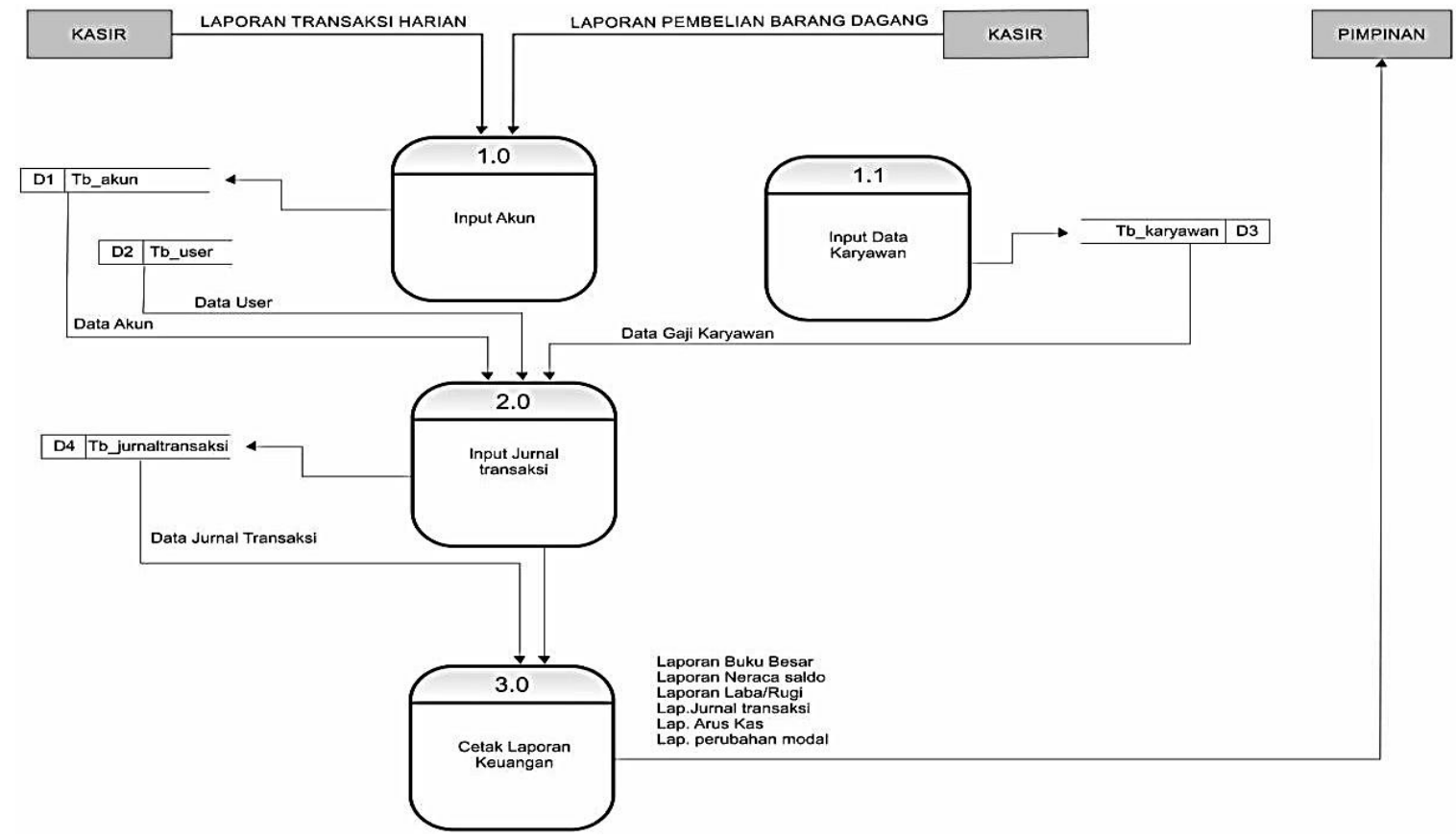

Gambar 4. Data Flow Diagram Level 1

b. Data flow diagram (DFD) Level 2 untuk proses 3

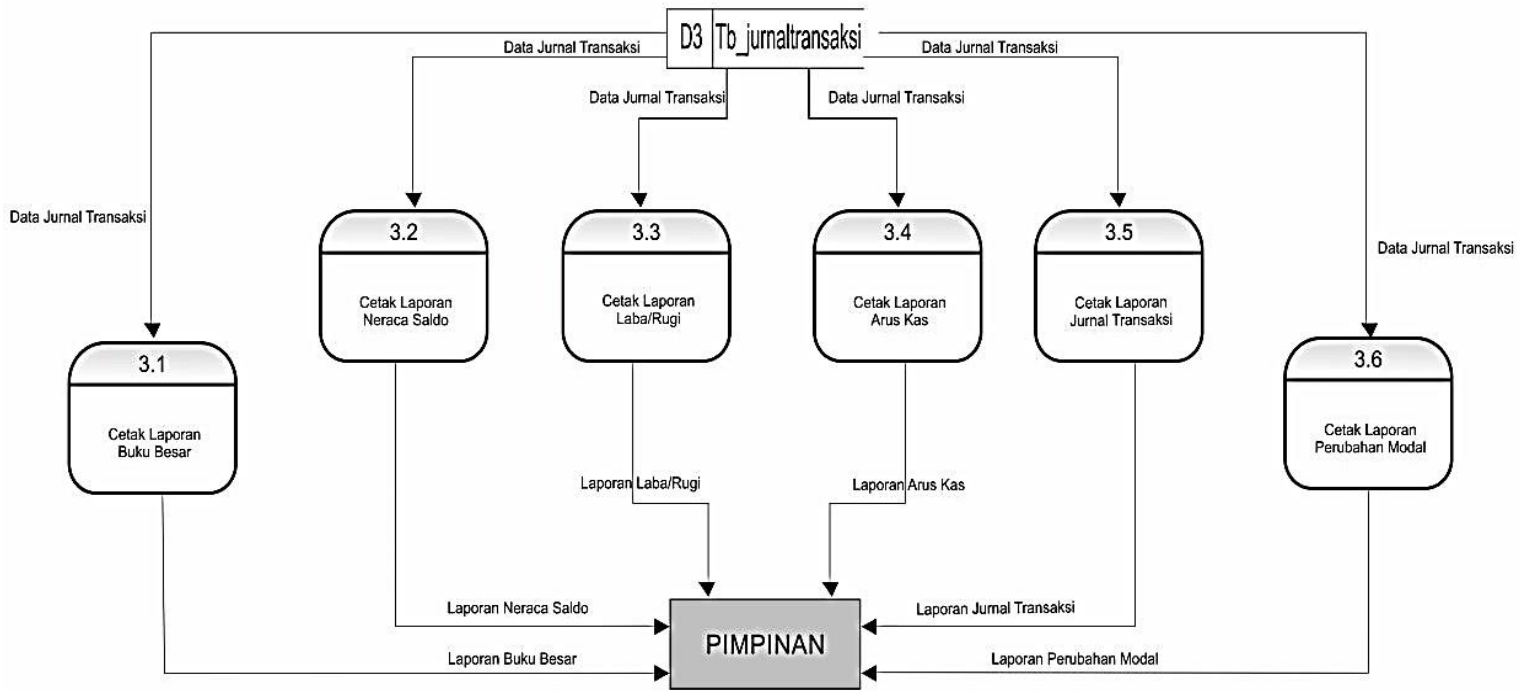

Gambar 5. Data Flow Diagram (DFD) Level 2 untuk proses 3

\section{Entity Relationship Diagram}

ERD merupakan suatu model untuk menjelaskan hubungan antar data dalam basis data, berdasarkan suatu persepsi bahwa real word terdiri dari objek dasar yang mempunyai hubungan atau relasi antar objek. Model entity relationship adalah suatu penyajian data dengan menggunakan entity dan relationship. (Siswanto dkk, 2014)
Entity Relationship Diagram (ERD) menggambarkan hubungan / relasi antara atribut-atribut yang terdapat pada konseptual sistem secara berbeda yang terdiri dari entity atribut-atribut yang ada. Bentuk entity relationship diagram boutiqe yang digunakan dapat dilihat pada gambar 6 berikut ini : 


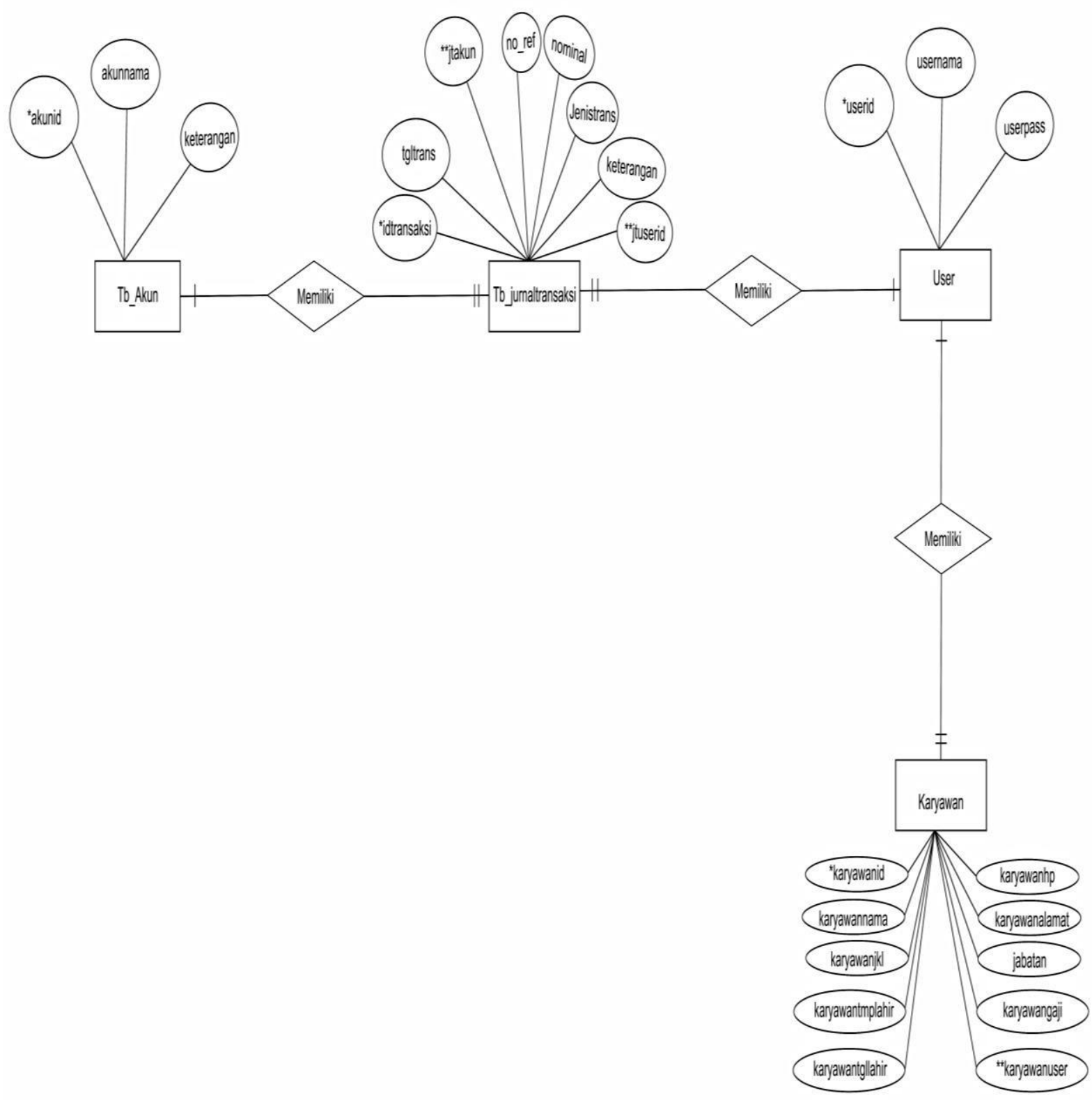

Gambar 6. Entity Relationship Diagram (ERD)

\section{Desain Output}

Tujuan akhir dari suatu sistem adalah dapat menyajikan suatu informasi atau pun output dengan cepat dan akurat. Untuk itu dalam pendesainan output ini perlu kita cermati output apa saja yang akan kita sajikan dan apa saja yang menjadi isi dari output tersebut. Adapun bentuk desain output yang dirancang adalah sebagai berikut:
1. Laporan Buku Besar

SituS Boutioue

Jl.Diponegoro No.17 L Padang

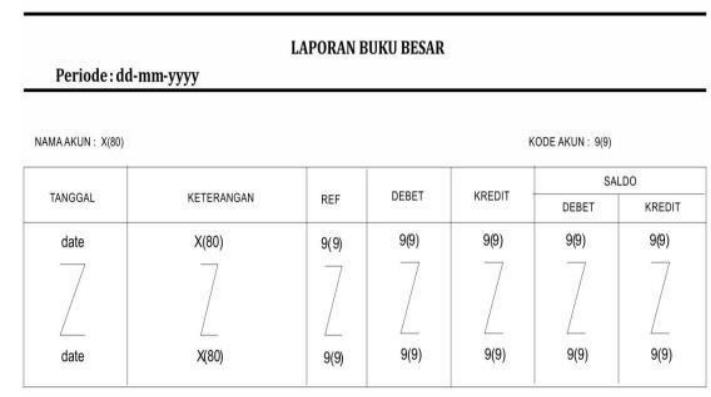

Gambar 7. Laporan Buku Besar 
2. Laporan Neraca

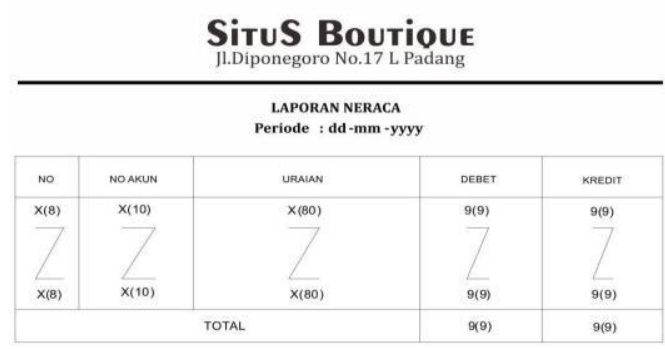

Gambar 8. Laporan Neraca

3. Laporan Laba/Rugi

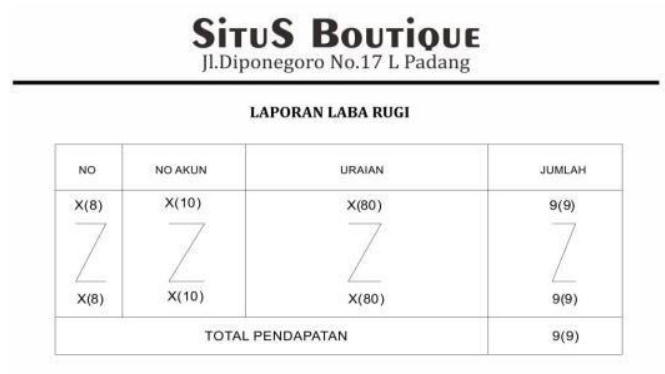

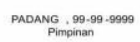

Gambar 9. Laporan Laba/Rugi

4. Laporan Arus Kas

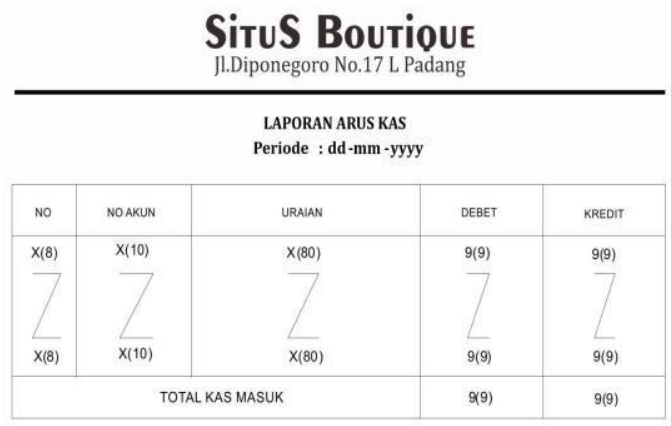

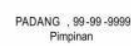

Gambar 10. Laporan Arus Kas

5. Laporan Jurnal Transaksi

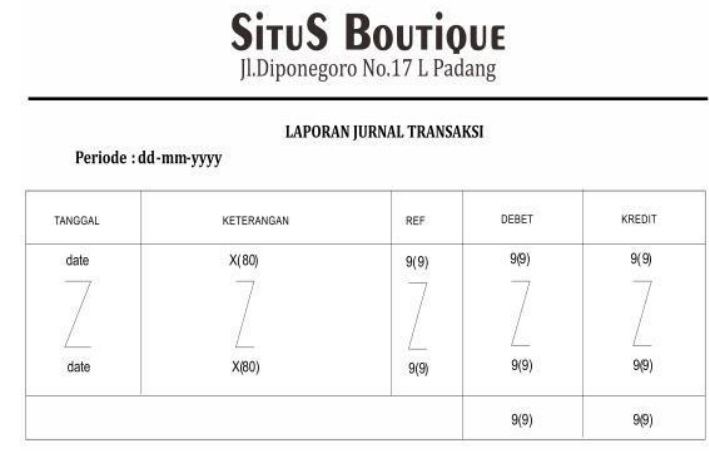

Gambar 11. Laporan Jurnal Transaksi

6. Laporan Perubahan Modal

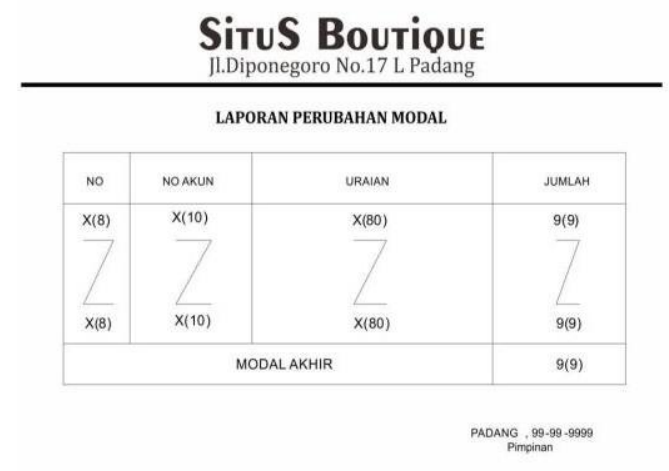

Gambar 12. Laporan Peubahan Modal

\section{Desain input}

Perancangan input merupakan proses perancangan bentuk format layar untuk mengelola data dalam table atau tabel seperti menambah atau menginput, menyimpan dan lain-lain di media penyimpanan. Rancangan ini didisain secara menarik dan mudah dioperasikan oleh user. Perancangan input dapat dilihat pada gambar berikut :

1. Form Login

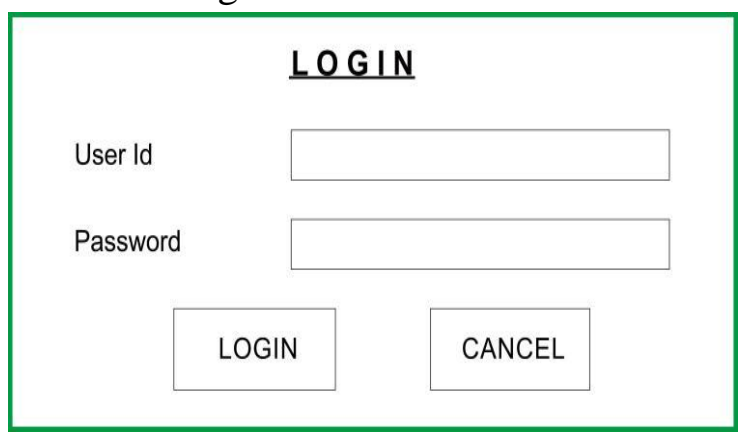

Gambar 13. Form Login

2. Form Akun 


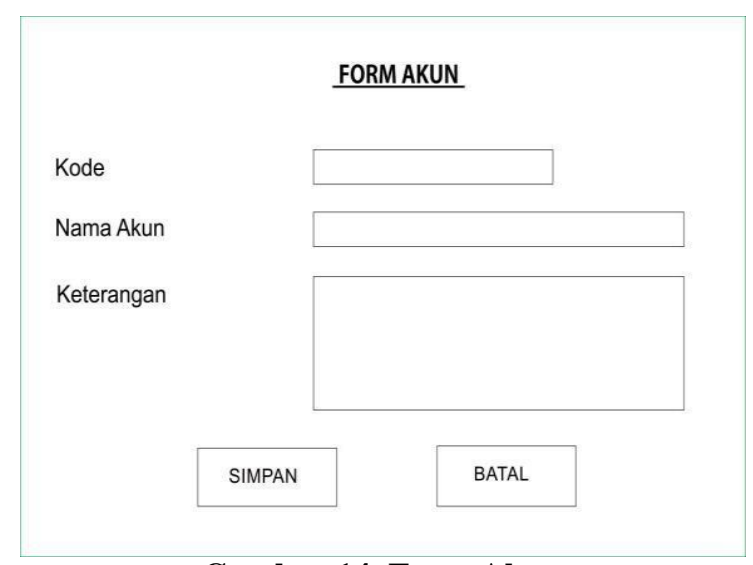

Gambar 14. Form Akun

3. Form Karyawan

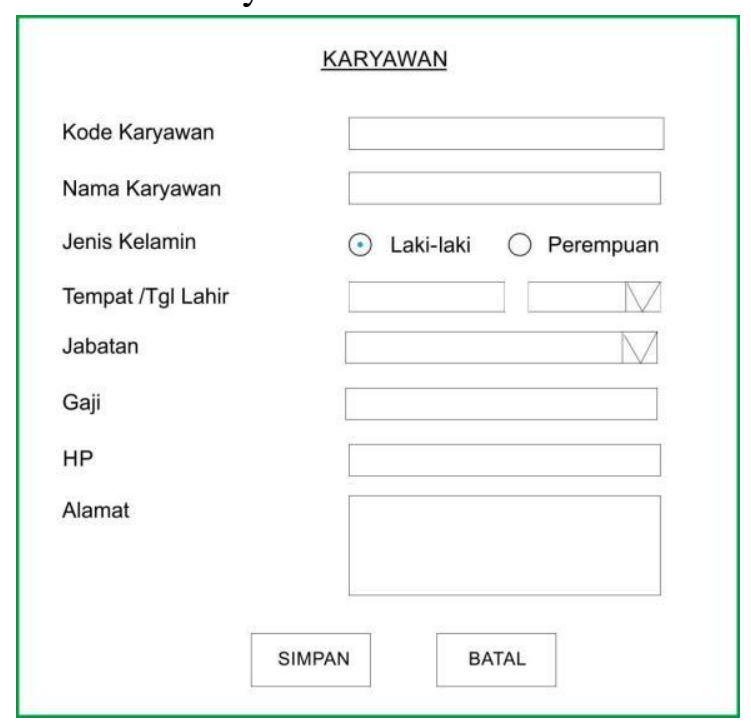

Gambar 15. Form Karyawan

\section{Form Jurnal Transaksi}

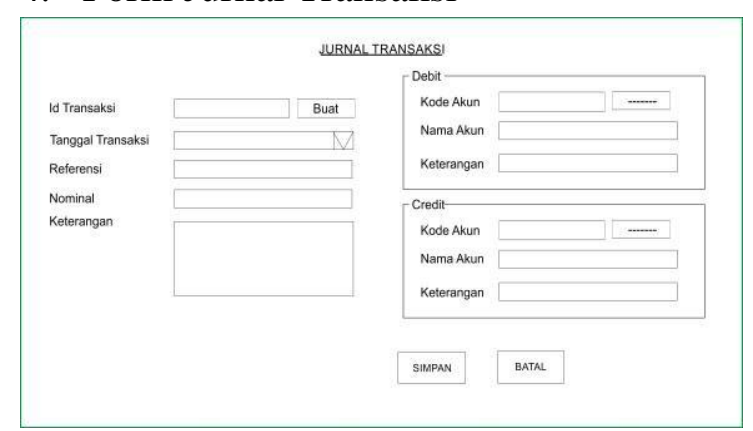

Gambar 16. Form Jurnal Transaksi

\section{SIMPULAN}

Berdasarkan penelitian yang telah dilakukan terhadap permasalahan mengenai sistem informasi Accounting pada Situs Boutique Padang, dan dilandasi dengan teori-teori serta didukung oleh sarana yang dibutuhkan dalam penelitian serta solusi yang dibutuhkan dari permasalahan tersebut. Maka dari itu penulis dapat mengambil beberapa kesimpulan yaitu :

1. Dengan adanya rancangan dan analisa sistem yang diusulkan memudahkan pimpinan dalam proses pengolahan laporan keuangan.

2. Dengan aplikasi ini dapat menyimpan data dengan baik ke dalam database sehingga dapat menghasilkan laporan yang cepat, tepat dan akurat disetiap bulannya.

3. Penerapan sistem informasi yang menggunakan Microsoft Visual Basic 2005 ini dapat membantu meningkatkan proses laporan keuangan kepada pimpinan baik itu dalam segi penyediaan informasi maupun kecepatan dalam memberikan informasi.

\section{UCAPAN TERIMAKASIH}

Terima kasih saya ucapakan untuk Institut Teknologi Batam dan LPPM ITEBA yang memberikan peluang dan bantuan dalam melakukan penelitian ini.

\section{DAFTAR PUSTAKA}

Asmara, Rini. 2014. "Sistem Informasi Penjadwalan Kuliah Studi Kasus : Institut Agama Islam Negeri (IAIN) Imam Bonjol Padang".Jurnal TEKNOIF. Vol. 2 No 1.

Hasibuan, Malayu. 2009. Manajemen Sumber Daya Manusia:Pengertian Dasar, Pengertian, dan Masalah. Jakarta: PT. Toko Gunung Agung, Jogiyanto. 2005, Analisa dan Desain Sistem Informasi, Penerbit Andi, Jakarta. Kadir, Abdul. 2010. "Mudah Mempelajari Database MySQL". Yogyakarta : Andi Offset. 
Luluk Setyo Handoko dan Bambang Eka Purnama. 2012. "Sistem Informasi Pengolahan Data Iklan pada Stasiun Radio Pas FM Pati Berbasis Web". Seruni FTI UNSA 2012 Volume 1 ISSN 2302-1136 (Print) - 20880154(Online).

Muh. Nur Luthfi Azis da Sukardi. 2012. "Analisis dan Perancangan Sistem Informasi Pengolahan Data Pernikahan pada Kantor Urusan Agama Kecamatan Kabonagung". Seruni FTI UNSA 2012 Volume 1 ISSN 2302-1136 (Print) - 20880154(Online).
Susanto. 2004. "Pengantar Manajemen". Jakarta : Bumi Aksara.

Ummu Latifah dan Sukadi. 2012. "Rancang Bangun Sistem Informasi Manajemen Pendonoran Darah pada Udd PMI Kabupaten Pacitan". Seruni FTI UNSA 2012 Volume 1 ISSN 23021136 (Print) - 2088-0154(Online).

Weygandt, Jeffry J., Donald E. Kieso, Walter G. Kell. Accounting Principles 4th Edition. New York: John Wiley \& Sons, Inc., 1996.

Yakub. Pengantar Sistem Informasi, Yogyakarta: Graha Ilmu.2012 